\title{
IAMJ
}

INTERNATIONAL

AYURVEDIC

MEDICAL JOURNAL

$\underline{\text { Review Article }}$

ISSN: 2320-5091

Impact Factor: 6.719

\section{CRITICAL STUDY OF TVAK IN THE VIEW OF MODERN SCIENCE:} A REVIEW ARTICLE

\author{
Ishan Malhotra ${ }^{1}$, Sakshi $^{2}$, Subhash Upadhyay ${ }^{3}$ \\ ${ }^{1}$ PG Scholar, Dept. of Rachana Sharir \\ ${ }^{2}$ Assistant Professor, Dept. of Rachana Sharir \\ ${ }^{3}$ Professor \& H.O.D., Dept. of Rachana Sharir \\ Sriganganagar College of Ayurvedic Science \& Hospital, Tantia University, Sriganganagar - 335001, India
}

Corresponding Author: docmalhotra88@gmail.com

\section{https://doi.org/10.46607/iamj3109082021}

(Published Online: August 2021)

Open Access

(C) International Ayurvedic Medical Journal, India 2021

Article Received: 19/07//2021 - Peer Reviewed: 01/08/2021 - Accepted for Publication: 02/08/2021

\section{Check for updates}

\begin{abstract}
In Ayurveda, the term Tvak, Twacha and Charma are frequently used to denote the skin. Tvak is described as the organ which covers the external surface of the entire body. Tvak and its related diseases have great importance because these are easily noticeable. It is the first part of the body that is in direct contact with any harmful substances or infective microorganisms. It protects the internal structures of the body from injury or infections and regulates the temperature of the body. Skin is also the beauty of a human being. Therefore, it should be protected from any abnormal conditions. Ayurveda Acharyas have described Tvak many years ago. They explained each layer of Tvak in meaningful sequences, its related diseases and measurement of each layer. They also explained that it maintains the normal colour of individuals and conveys the sensation of touch. Some topics of Ayurveda are easy to understand, and some topics become easy if we study along with modern science. So, for a proper understanding of the concept of Tvak, it is very essential to correlate it with modern science and elaborate according to the modern era.
\end{abstract}

Keywords: Tvak, Sparshanendriya, Sharirsthan, Santanika, Vrihi, Skin, Dermis, Epidermis 


\section{INTRODUCTION}

Tvak is explained as an external covering of the body by Acharyas. It is considered as a seat of Sparshanendriya which comes under Panchagyanendriya. Acharya Sushrut has described seven layers of Tvak with measurement of each layer and diseases occurring on it. AcharyaVagbhat has the almost same opinion about Tvak, but Acharya Charaka's opinion is different. Acharya mentioned six layers of Tvak and its related diseases. Seven layers explained by Sushrut are Avabhasini, Lohita, Shweta, Tamra, Vedini, Rohini and Mamsadhara in sequence from outer to inner. According to modern science, the skin is considered the largest organ of the body. It covers the whole body externally and is part of the integumentary system. Skin is mainly of two types, epidermis (outer layer) and dermis (inner layer). The epidermis is subdivided into five layers whereas the dermis is divided into two layers. The thickness of the skin is variable from 0.5 to $5 \mathrm{~mm}$ depending upon different parts of the body.

\section{REVIEW OF TVAK:}

The word 'Tvak' is derived from the Sanskrit root (mooladhatu) 'Tvak samvarne' which means the structure that protects and covers the entire body. Tvak is the Upadhatu of Mamsadhatu, Moolasthan of Mamsavaha Storas and is a site of Bhrajaka pitta. Tvak is mentioned as the adhishthana of Sparshanendriya which is one of the five Gyanendriya and its function is Sparshagyana (sensation of touch). It is Panchabhautika with a predominance of $\mathrm{Va}$ - yumahabhuta ${ }^{6}$ According to Acharya Charak, there are six layers of skin in the body. An Outermost layer is called Udakadhara, the second one is Asrigadhara, the third layer is the site of the origin of Sidhma and Kilasa, fourth one is the site of the origin of Dadru and Kushtha, fifth is the site of the origin of Alaji and Vidradhi. The sixth layer is that which cuts causes loss of consciousness and is the site of the origin of Arunshi, being manifested as blackish red and deeprooted on joints and is hardly curable. Thus, the six layers of skin cover the Shadanga (Six regions) of the body. According to Acharya Sushrut, the combined form of Shukra (spermatozoon) and Shonita (ovum) has been processed by the heat of the body then the formation of seven Tvak (skin) occurs, just like the formation of Santanika (cream) when milk is boiled. Among these, the first Tvak is named by Avabhasini which expresses all the Varna (colour), illumines the five kinds of Chhaya (Shades of colours) and is the site of Sidhma and Padmakantaka. Second is Lohita which is the site of Tilakalaka, Nyachchha and Vyanga. The third is Sweta which is the site of Charmadala, Ajagallika and Masaka. Fourth, Tamra is the site of many kinds of Kailasa and Kushtha. Fifth, Vedini is the site of Kushtha and Visarpa. Sixth, Rohini is the site of Granthi, Apachi, Arbuda, Shlipada and Galganda. The Seventh Tvak is named by Mamsadhara. It is the site of Bhagandara, Vidradhi and Arsha.

Sushrut has also explained the thickness of each Tvak which are as follows-

\begin{tabular}{|l|l|l|}
\hline S. No & Tvak & Thickness \\
\hline 1. & Avabhasini & 18th part of Vrihi \\
\hline 2. & Lohita & 16th part of Vrihi \\
\hline 3. & Sweta & 12th part of Vrihi \\
\hline 4. & Tamra & 8th part of Vrihi \\
\hline 5. & Vedini & 5th part of Vrihi \\
\hline 6. & Rohini & Equal to Vrihi \\
\hline 7. & Mamsadhara & Equal to 2 Vrihi \\
\hline
\end{tabular}

Acharya Vagbhat has also accepted that there are seven layers of Tvak in the body which are formed by the heating process of Asrij (Blood), just like the formation of Santanika (cream) when milk is boiled. 
Review Of Skin: Skin or integument consists of two layers, the superficial epidermis and deep dermis.

Epidermis-: It is nonvascular and is formed by stratified epithelium which is made up of five layers-

1. Stratum corneum -: It is the outermost layer of the skin and consists of dead cells called corneocytes. These cells lose their nucleus due to pressure and become dead cells. The cytoplasm is flattened with a fibrous protein called keratin. These cells also contain phospholipids and glycogen.

2. Stratum lucidum -: It is made up of flattened epithelial cells. This layer is present in a thick cell only. It is translucent and barely visible. Many cells have degenerated nucleus, and, in some cells, the nucleus is absent.

3. Stratum granulosum-: This is the third layer with 2 to 5 rows of flattened rhomboid cells. The cytoplasm contains kerato- hyaline granules. The protein keratohyalin is the precursor of keratin.

4. Stratum spinosum-: This layer consists of 4 to 6 rows of cells. This layer is also known as the prickle cell layer because the cells of this layer possess some spine like protoplasmic projections. By these projections, the cells are connected.

5. Stratum germinativum-: It is also called stratum basale because it is the deepest or basal layer of the epidermis. This is a thick layer made up of polygonal cells superficially and columnar or cuboidal epithelial cells in the deeper parts. Here, new cells are constantly formed by mitotic division. The stem cells which give rise to new cells are known as keratinocytes. The colour of the skin depends upon the cells of this layer which contain the pigment melanin.

Dermis: It is vascular and is characterized by dense irregular connective tissue. It is made up of 2 layers namely-

1. Superficial papillary layer-: This layer projects into the epidermis. This contains blood vessels, nerve fibres, lymphatics and has some pigmentcontaining cells known as chromatophores.

2. Deeper reticular layer-: This layer is made up of reticular and elastic fibres which are found around the hair bulbs, sebaceous glands and sweat glands. It is a loose connective tissue that connects the skin with the internal structures of the body. This serves as an insulator to protect the body from excessive heat and cold in the environment. A lot of smooth muscles called arrector pili are also found in the skin around the hair follicles.

The thickness of skin: The average thickness of the skin is about 1 to $2 \mathrm{~mm}$, but it is not uniformly thick. In some places, it is thick, and, in some places, it is thin. In the sole, palm and interscapular region, it is considerably thick, measuring about $5 \mathrm{~mm}$. In other areas of the body, the skin is thin. It is the thinnest over eyelids and penis measuring about $0.5 \mathrm{~mm}$ only. The basic histology of the skin is similar in different regions of the body, except regarding the thickness of the epidermis. Palms and Soles are constantly exposed to increased wear, tear, and abrasion. As a result, the epidermis in these regions is thick and skin is called thick skin. It also contains sweat glands but lacks hair follicles, smooth muscle fibres, and sebaceous glands. The remainder of the body is covered by a thin skin. In these regions, the epidermis is thinner than thick skin. Thin skin contains hair follicles, sweat glands and sebaceous glands. Attached to the connective tissue sheath of hair follicles and connective tissue of the dermis are smooth muscle fibres called arrector pili.

\section{Functions of the Skin:}

1. A skin forms the covering of all the organs of the body and protects these organs from bacteria, toxic substances, mechanical blow, and ultraviolet rays.

2. The skin has many nerve endings which are cutaneous receptors, and these receptors are stimulated by pain, touch, pressure, or temperature sensations and convey these sensations to the brain via afferent nerves.

3. Vitamin $D_{3}$ is synthesized in the skin by the action of ultraviolet rays on cholesterol.

4. Skin plays an important role in the regulation of body temperature, water balance and electrolyte balance. 
5. Skin absorbs fat-soluble substances and some ointments.

6. The skin excretes waste materials like urea, salts, and fatty substance.

7. Skin secretes sweat through sweat glands and sebum through sebaceous glands.

\section{DISCUSSION}

After studying the reviews of Tvak and skin, many points came out which show similarities between each other. According to Ayurveda Tvak covers the external surface of the entire body. Modern science has also explained that skin is the outermost covering of the body which provides a barrier between muscles, organs, tissues, bones of the body and the outside environment. This barrier protects the body from microorganisms, chemical exposure and changing temperatures. Acharya Sushrut and Vagbhat have mentioned seven layers of Tvak whereas Acharya Charak has mentioned six layers while modern science has also considered seven layers of skin under the epidermis and dermis layer. So, we can correlate the seven layers of Tvak as explained by Sushrut, with seven layers of skin as explained by modern science. According to Ayurveda, Tvak is mentioned as the Adhishthana (site) of Sparshanendriya which is one of five Gyanendriya. It is responsible for the sensation of touch. Modern science has also considered that the skin is one of five sensory organs which is also responsible for the sensation of touch and temperature. Ayurveda has explained different layers of Tvak as the sites of origins of many diseases like Sidhma, Padmakantak, Kushtha, Visarpa etc. These diseases are originated from a layer of Tvak. According to modern science, skin is also the main site of many diseases like eczema, psoriasis, leprosy, acne etc. Many diseases are related to the epidermis, and many are related to the dermis layer of skin.

According to Ayurveda, Tvak is the site of Bhrajak pitta which is one of five Pittas. Bhrajak pitta is responsible to reflect Varna (colour) and Chhaya (shades of colours) and regulates the temperature of the body. Modern science has explained melanin pigments which are like Bhrajak pitta because the functions of both are the same. Melanin pigments determine the colour of the skin of individuals. Tvak is Panchbhautik with a predominance of Vayu Mahabhuta. This Vayu conveys the Sparsh (touch) sensation of Sparshanendriya to the brain. According to modern science, many nerve endings are present in the skin which receives the sensation of touch, pain, and temperature as an impulse and then this impulse is conveyed to the brain through the nerve pathway. The brain reads this impulse, and we feel the sensations. Acharya Sushrut has explained the thickness of each layer of Tvak. Acharya measured the thickness by Vrihi (barley or rice). If we measure the total thickness of Tvak, it will be 3 to 4 Vrihi. Thickness increases continuously from outer Avabhasini (first layer) to inner Mamsadhara (last layer). This thickness is only on muscular regions and not on all regions of the body. According to modern science, the thickness of the skin is about 0.5 to $5 \mathrm{~mm}$ with an average of 1 to $2 \mathrm{~mm}$. Modern science also accepts that the thickness of the skin is not equal on every part of the body. Because of this, the skin is divided into thick and thin skins. As mentioned in Ayurveda, same the inner layer of skin (dermis) is thicker than the outer layer (epidermis). So, the measurement of the thickness of Tvak as described by Acharya Sushrut is much close to modern science. Skin is having many important functions which are mainly protective. It synthesizes Vit. $\mathrm{D}_{3}$ helps in receiving the sensation, regulates body temperature, maintains water and electrolyte balance, and excretes harmful waste materials. Skin is composed of hairs, nails, sweat glands, sebaceous glands, and numerous openings. Sweat glands excrete the waste materials of the body through sweat and sebaceous glands keep the skin's surface oily.

\section{CONCLUSION}

Tvak, according to Ayurveda, and skin, according to modern science have great similarities based on several layers, total thickness, variation of outer to inner thickness, functions, morphology, and diseases affection it. Sushruta's description regarding Tvak is more scientific, very systematic and one step ahead of 
modern science because explanations about thickness, function and disease affection of each layer are very clear which is lacking in modern science. Thus, the present study will be very helpful to understand the concept of Tvak and the concept of skin also. It is also helpful to manage some skin diseases that occur in different layers of skin.

\section{REFERENCES}

1. Dikshita Bhanuji, Amarkosha of Amarsimha, first edition, Chaukhamba Sanskrit series Varanasi-1, Page 168

2. Shastri Kashinath, Charaksamhita part-2, Reprint 2004, Chukhamba Bharati academy Varanasi, Chikitsasthan, Chapter 15, Verse 17, Page 456

\section{Source of Support: Nil \\ Conflict of Interest: None Declared}

How to cite this URL: Ishan Malhotra et al: Critical Study Of Tvak In The View Of Modern Science: A Review Articl. International Ayurvedic Medical Journal \{online\} 2021 \{cited August 2021\} Available from: http://www.iamj.in/posts/images/upload/1795_1799.pdf 